\title{
Incompatibility of national law with the African Charter on Human and Peoples' Rights: Does the African Court on Human and Peoples' Rights have the final say?
}

\author{
Amos O Enabulele* \\ Associate Professor, Department of Jurisprudence and International Law, \\ Faculty of Law, University of Benin, Nigeria; Visiting Scholar, University of \\ Reading, United Kingdom
}

\begin{abstract}
Summary
This article considers the effect of a declaration by the African Court on Human and Peoples' Rights that a municipal law is incompatible with the provisions of the African Charter on Human and Peoples' Rights in light of the decision of the African Court in Tanganyika Law Society \& Another v Tanzania. It argues that such a decision should have implications for all parties to the African Charter, especially those states that are also parties to the African Court Protocol. The article recognises that this effect is not automatic as the decisions of the Court are denied this expected effect under municipal law by several factors, one of which is the hostility of municipal institutions to an international court judgment that seeks to nullify the established municipal legal status quo.
\end{abstract}

Key words: incompatibility; African Court; African Charter; Tanganyika Law Society; African Commission

* LLB LLM (Benin), PhD (Brunel, London); amos.enabulele@uniben.edu 


\section{Introduction}

The African Court on Human and Peoples' Rights (African Court) is a judicial institution established as one of the enforcement mechanisms of the African Charter on Human and Peoples' Rights (African Charter). ${ }^{1}$ The African Charter $^{2}$ is the principal human rights instrument of the African Union (AU). It has been ratified by 53 of the 54 states of the $\mathrm{AU}$; only South Sudan was yet to ratify it as at the time of writing. ${ }^{3}$

Since the African Court came into being in 2004, there has been very little opportunity to test the responses of member states to adverse judgments delivered in favour of individuals, as the Court has delivered only four final judgments ${ }^{4}$ of the total of 20 cases it has so far finalised. ${ }^{5}$ Two factors account for this. The first is the failure of respondent states to make the declaration required under article 34(6) of the Protocol to the African Charter on Human and Peoples' Rights on the Establishment of an African Court on Human and Peoples' Rights (African Court Protocol) to grant individuals the right to invoke the jurisdiction of the Court against them; the second is the failure of applicants to exhaust domestic remedies.

The purpose of establishing the African Court, as clearly set out in the Preamble and article 2 of its Protocol, is to contribute to the implementation of the safeguards of the African Charter. This it would do in two significant ways, the first being through findings of specific instances of a violation of rights guaranteed to individuals by the Charter; and the second through findings of incompatibility of the laws of member states with the provisions of the Charter. ${ }^{6}$ The latter category is more complicated and poses much more difficulty of satisfaction, especially if the incompatible provisions are of a constitutional nature. Satisfaction in respect of this category would require the affected state to amend or repeal the law or laws that have been found to be incompatible with the African Charter. It also has

1 See the Protocol to the African Charter on Human and Peoples' Rights on the Establishment of an African Court on Human and Peoples' Rights, adopted June 1998, entered into force January 2004.

2 Adopted 27 June 1981, entered into force 21 October 1986, CAB/LEG/67/3/Rev. 5; reprinted in C Heyns \& M Killander (eds) Compendium of key human rights documents of the African Union (2013) 29.

3 http://www.achpr.org/instruments/achpr/ratification/ (accessed 8 February 2016).

4 The cases are Application 009/2011 Tanganyika Law Society \& Another $v$ Tanzania (consolidated with Mtikila v Tanzania Application 011/2011); Application 013/ 2011 Abdoulaye Nikiema, Ernest Zongo, Blaise Ilboudo \& Burkinabe Human and Peoples' Rights Movement $v$ the Republic of Burkina Faso; Application 004/2013 Lohe Issa Konate v Burkina Faso; Application 005/2013 Alex Thomas $v$ Republic of Tanzania. See http://en.african-court.org/\#finalised-cases (accessed 4 February 2016.)

5 As above.

6 M Mutua 'The African human rights court: A two-legged stool?' (1999) 21 Human Rights Quarterly 342362 (differentiating cases of specific violations from those that expound the African Charter). 
ramifications for states that were not parties to the case in which the finding of incompatibility was made if they are parties to the Constitutive Act of the AU, the African Charter and the African Court Protocol. It will in some ways, albeit restricted, have ramifications for state parties to the African Charter and the Constitutive Act that are yet to ratify the Court Protocol. Significantly, however, such a finding may negatively affect the choice of states that are considering ratifying the African Court Protocol.

In Tanganyika Law Society \& Another $v$ Tanzania, $^{7}$ the African Court had its first exposure to the problem of satisfaction of a judgment declaring the law of a state incompatible with a provision of the African Charter. Using this case as a focal point, the article is aimed at showing that it is possible to hold all state parties to both the Charter and the African Court Protocol bound by the general principles in a judgment in which the law of a state party is declared incompatible with the Charter. As a result, all state parties to both instruments maintaining similar laws are, by the jurisprudential weight of the judgments of the African Court, under an obligation to amend their laws with a view to bringing them in tune with the authoritative interpretation of the Charter by the Court.

\section{Access to the African Court on Human and Peoples' Rights}

The African Court is a continental human rights court established by the Organisation of African Unity (OAU) (now AU) in article 1 of the African Court Protocol. The Protocol has now been ratified by 30 states: Algeria; Benin; Burkina Faso; Burundi; Cameroon; Chad; Congo; Comoros; Côte d'Ivoire; Gabon; The Gambia; Ghana; Kenya; Lesotho; Libya; Malawi; Mali; Mauritania; Mauritius; Mozambique; Niger; Nigeria; Rwanda; Sahrawi Arab Democratic Republic; Senegal; South Africa; Tanzania; Togo; Tunisia; and Uganda. ${ }^{8}$

Article 5 of the Protocol provides for three routes through which the African Court may address human rights claims made under the African Charter. The first is through article 5(1)(a), which allows the African Commission on Human and Peoples' Rights (African Commission) to submit claims on behalf of individuals. The second is through articles 5(1)(b) and (d), under which a state may submit 'disputes ... concerning the interpretation and application of the

7 n 4 above. See $O$ Windridge 'A watershed moment for African human rights: Mtikila \& Others $v$ Tanzania at the African Court on Human and Peoples' Rights' (2015) 15 African Human Rights Law Journal 299328.

8 See list of countries which have signed, ratified/acceded to the Protocol to the African Charter on Human and Peoples' Rights on the Establishment of an African Court on Human and Peoples' Rights (accessed on the AU website http:// www.au.int (accessed 31 May 2016)). This information was last updated 1 April 2016. 
Charter', ${ }^{9}$ either as a purely interstate claim under article 5(1)(b) or one arising from the violation of the Charter rights of a national of the claimant state by the respondent state under article 5(1)(d). To the latter kind of claim, the restriction in article $34(6)$ of the Protocol is irrelevant.

The third is through article 5(3), which allows individuals and nongovernmental organisations (NGOs) to directly seize the African Court against a state party to its Protocol, subject to article 34(6) of the Protocol by which, unless a state makes a declaration permitting it, the Court lacks jurisdiction to receive cases filed against the state by individuals and NGOs. Out of the 30 states that have so far ratified the Protocol, only seven states - Burkina Faso, Côte d'Ivoire, Ghana, Malawi, Mali, Rwanda and Tanzania - have made the article 34(6) declaration. ${ }^{10}$ This has so far diminished the role of individuals as the principal guardians of the legal integrity ${ }^{\prime 11}$ of the African Charter, as a continental instrument, given the fact that without individual litigants, there would hardly be cases presented to the Court.

\section{Tanganyika Law Society \& Another v Tanzania}

In this case, the applicants brought separate applications before the African Court on the claim that Tanzania had, through certain amendments to its Constitution, violated its citizens' right of association, namely, the right to participate in public or governmental affairs, among others. The applications were later consolidated.

The applicants prayed the African Court to declare that Tanzania was in violation of, inter alia, articles 10 and 13(1) of the African Charter. Article 10(1) provides for freedom of association, while article 13(1) provides for the right of every citizen to participate freely in the government of his or her country. Based on these provisions, the applicants urged the Court to direct the respondent to put the necessary constitutional, legislative and other measures in place to give effect to the rights contained in the aforementioned provisions and to report compliance to the Court within a 12-month period. In its defence, the respondent argued that the prohibition of

\section{$9 \quad$ Art 3(1).}

10 See $\mathrm{n} 8$ above; http://en.african-court.org/ (accessed 13 May 2016). Rwanda, however, withdrew its declaration on 29 February, 2016. The notice of withdrawal was contained in a press statement issued by the Rwandan Ministry of Justice. See http://www.minijust.gov.rw/fileadmin/Documents/Photo_News_2016/Clarifica tion2.pdf (accessed 13 May 2016).

11 D Starr-Deelen \& B Deelen 'The European Court of Justice as a federator' (1996) 26 Federalism and the European Union 81 84; dissenting opinion of SAB Akuffo, BM Ngoepe and EN Thompson JJ in Application 001/2008 Michelot Yogogombaye $\checkmark$ Republic of Senegal para 16 (observing that art 36(4) is at odds with the 'objective, language and spirit of the Charter' as it disables the African Court from hearing applications brought by individuals against a state that has not made a declaration); J Mubangizi \& A O'Shea 'An African Court on Human and Peoples' Rights' (1999) 24 South African Yearbook of International Law 256264. 
independent candidacy in Tanzania was dependent on the social needs of the country, based on its historical reality, and that the restriction was a means for avoiding absolute and uncontrolled liberty.

To adequately deal with the issues raised, the African Court also considered the limitations in articles 27(2) and 29(4) of the African Charter. The former provides that ' $[t]$ he rights and freedoms of each individual shall be exercised with due regard to the rights of others, collective security, morality and common interest'; the latter places a duty on individuals ' $[\mathrm{t}] \mathrm{o}$ preserve and strengthen social and national solidarity, particularly when the latter is threatened'.

In its judgment, the African Court produced a long and detailed reasoning, part of which is stated below. The Court began by noting that the rights guaranteed under article 13(1) are individual rights which are not intended to be enjoyed only in association with some other individuals or groups of individuals, such as political parties. ${ }^{12}$ The Court therefore reasoned that the pertinent question was whether an individual's right was in jeopardy and not whether he can enjoy the right as member of an association. Accordingly, the Court held that a requirement that a candidate must belong to a political party before he or she is able to participate in the governance of Tanzania derogates from the rights enshrined in article 13(1) of the African Charter. $^{13}$

There was, however, the question of whether the decision to exclude independent candidacy was justified as a necessary derogation from the right in article 13(1) within the permissive provisions of article 27 of the Charter. To determine this question, the Court distinguished the Tanganyika case from the decision of the Inter-American Court of Human Rights in Castañeda Gutman $v$ Mexico, ${ }^{14}$ which was heavily relied upon by Tanzania. Here, the InterAmerican Court acknowledged that the permission or prohibition of independent candidacy could be justified by different social needs, such as expanding and improving participation and representation in the management of public affairs or for the purpose of strengthening political organisations as essential instruments of democracy. It was held that Mexico was justified in the registration of candidates exclusively through political parties in response to the compelling social needs, based, inter alia, on diverse historical, political and social grounds, and the need to create and strengthen the party system as a response to historical and political reality, ${ }^{15}$ particularly that the applicant had the option either to be sponsored by a political party without necessarily joining that party or to form his own political

12 Tanganyika Law Society (n 4 above) para 98.

13 Tanganyika Law Society para 99.

146 August 2008 Ser C 184.

15 Castañeda Gutman (n 14 above) paras 192-193. 
party and that the requirements for forming political parties were not arduous. 16

Distinguishing this case, the African Court reasoned that, unlike the finding of the Inter-American Court in Castañeda Gutman v Mexico, no other option existed for citizens desirous of seeking political offices in Tanzania without first becoming members of, and be sponsored by, a political party. ${ }^{17}$ The African Court accepted the view that the right to stand for election should not be limited unreasonably by requiring candidates to be members of any or a specific political party. ${ }^{18}$

Consequently, the Court held that the jurisprudence regarding restrictions on the exercise of rights has developed the principle that every 'formality', 'condition', 'restriction' or 'penalty' imposed must be a restriction of general application that is necessary in a democratic society and is reasonably proportionate to the legitimate aim pursued. ${ }^{19}$ Furthermore, the Court accepted the view that the impact, nature and extent of any restriction of rights must be weighed against the legitimate state interest serving a particular goal and that the legitimate interest must be 'proportionate with, and absolutely necessary for the advantages which are to be obtained'. ${ }^{20}$

The African Court took the firm view that there was nothing in Tanzania's arguments to show that the restrictions on the exercise of the right to participate freely in the government of the country by prohibiting independent candidacy fell within the permissible restrictions set out in article 27(2) of the African Charter. The Court declared that the restriction on the exercise of the right to seek elective office by the prohibition of independent candidacy is not proportionate to the alleged aim of fostering national unity and solidarity.

Importantly, the Court found that the prohibition violated the right of the general populace to 'choose' as well as the right of an office seeker to 'freely participate' in the electoral processes. On the right to 'choose', the Court declared, based on article 27 of the Vienna Convention on the Law of Treaties (VCLT) of $1969,{ }^{21}$ that the African Charter imposes an obligation on Tanzania 'to make laws in line with the intents and purposes of the Charter' ${ }^{22}$ and that the restriction of the electorates' choice of candidates to those chosen by political parties 'is an unnecessary fetter that denies to the citizen the right of direct participation, and amounts to a violation' ${ }^{23}$ Concerning the right to free participation, the Court declared that the prohibition also

16 As above.

17 Tanganyika Law Society (n 4 above) para 107(3).

18 Tanganyika Law Society paras 17 \& 107(3).

19 Tanganyika Law Society para 106(1).

20 Tanganyika Law Society paras 106(1), (2) \& 107(1).

21 Art 27 provides that '[a] party may not invoke the provisions of its internal law as justification for its failure to perform a treaty'.

22 Tanganyika Law Society (n 4 above) para 110.

23 As above. 
violated the rights of citizens to freely participate in the government of the country and that, by requiring individuals to belong to a political party before seeking electoral office, the respondent violated the right to freedom of association.

\section{Legal implications for Tanzania and other states}

As stated earlier, a decision of incompatibility stands on a higher pedestal to, and is set on a wider range of application than a decision that simply finds a violation of the right of an individual. It carries implications for all the states over which the Court has jurisdiction if they are also parties to the interpreted instrument and, to some extent, affects states that are parties to the interpreted instrument but not parties to a court's protocol, where the court that made the interpretation is established under the regime of the interpreted instrument. This is what constitutes the difference between an interpretation of the African Charter given by the Economic Community of West African States (ECOWAS) Community Court of Justice (ECCJ), ${ }^{24}$ for instance, and that given by the African Court. It is not debatable that the decisions of the latter are more integral to the African Charter than those of any other court that also interprets and applies the Charter. However, the African Court has stated that it has no appellate jurisdiction over cases already decided by domestic, regional and similar courts. ${ }^{25}$

The importance of incompatibility findings, such as that in the Tanganyika case, is underscored by the uniform application of the African Charter across all state parties. Respect for an incompatibility finding across state parties brings about the unity of application of the Charter. When particularised to the state against which it was made, the Charter regime would be diminished by a vertical and horizontal discordant application of the Charter. There would remain disparate judicial interpretations of, and unregulated legislative constraints on, the Charter across member states and between member states and the African Court. Using the Tanganyika case as example, how can it be explained that independent candidacy is incompatible with the African Charter in Tanzania but not incompatible in Nigeria, Zambia and Sierra Leone? ${ }^{26}$ Zambia and Sierra Leone are yet to ratify the Court Protocol. The consequence of such disparity would be that uniformity and certainty would be replaced by 'jurisprudential/

24 Protocol A/P1/7/91 as amended by Supplementary Protocol A/SP 1/01/05.

25 Application 001/2013 Ernest Francis Mtingwi v Malawi para 14.

26 All three states constitutionally prohibit independent candidacy in such a way that totally excludes an individual who is not a member of a political party from the process. See secs 65(2)(b), 106(d) and 131(c) of the Constitution of the Federal Republic of Nigeria, 1999; art 34 of the Constitution of Zambia; and art 41 of the Constitution of Sierra Leone Act 6 of 1991. 
interpretational chaos' 27 as 'each state party ... [will] have its own level of protection based on their respective domestic laws'. ${ }^{28}$

An assertion that interpretations adopted by the African Court in a case have implications for third parties may on the face of it appear problematic and novel. However, it states nothing new when the binding effect of the Court's judgment is differentiated from its 'continuing applicability'29 as an authoritative interpretation of the African Charter that 'ensure[s] recognition of a situation at law'30 which, once established, 'the legal position ... cannot again be called in question in so far as the legal effects ensuing therefrom are concerned' ${ }^{31}$ Without a doubt, the rule that decisions are binding upon the parties only, being an 'intransgressible' ${ }^{32}$ principle of both municipal law and international law, applies in full force to decisions of the African Court. Apart from its status as a general principle of law recognised by civilised nations under article 38(1)(c) of the Statute of the International Court of Justice (IC) ${ }^{33}$ it is expressly provided for under article 59 of the same Statute. ${ }^{34}$ But the rule that judgments are binding upon the parties only cannot be exhaustive of all the uses to which judgments could be put, nor does it block the reformative power of the reasoning contained in a judgment within the sphere of the jurisdiction of the court that delivered it.

If we take a closer look at the IC], we see a segregated system that is based upon optional clause declarations, ${ }^{35}$ special agreements, 36 and compromissory clauses in treaties in force. ${ }^{37}$ The implication of the jurisdictional structure of the ICJ is that, notwithstanding that its Statute is an integral part of the United Nations (UN) Charter and thus as obligatory as the Charter itself, the jurisdiction of the Court is segmented according to the jurisdictional base(s) through which the Court exercises its jurisdiction over any particular state. ${ }^{38}$ In other

27 Scanlen \& Holderness v Zimbabwe (2009) AHRLR 289 (ACHPR 2009) para 115.

28 As above.

29 Northern Cameroons (Cameroon v United Kingdom) Preliminary Objections (1963) IC) Reports 1537.

30 Interpretation of Judgments Nos 7 and 8 (the Chorzow Factory) PCIJ Series A 1320.

31 As above.

32 Legality of the Threat or Use of Nuclear Weapons (1996) ICJ Reports 226257 para 79.

33 See CC Joyner 'UN General Assembly resolutions and international law: Rethinking the contemporary dynamics of norm creation' (1981) 11 California Western International Law Journal 445454 (stating that art 38 is 'the most convenient and concise statement regarding the sources of international law').

34 See Land and Maritime Boundary between Cameroon and Nigeria Preliminary Objections (1998) ICJ Reports 275292 para 28; East Timor case (Portugal $v$ Australia) (1995) ICJ Reports 90.

35 Art 36(2)

36 Art 36(1).

37 As above.

38 Mavrommatis Palestine Concessions Judgment 2 (1924) PCIJ Ser A 2 11-15; Armed Activities on the Territory of the Congo, Democratic Republic of Congo $v$ Rwanda) (2006) ICJ Reports 639 para 88 (holding that 'its jurisdiction is based on the consent of the parties and is confined to the extent accepted by them'). 
words, although states are generally parties to the Statute of the Court by reason of being parties to the UN Charter, they must be compartmentalised within one or sometimes more of these jurisdictional bases ${ }^{39}$ and this is the only means of forming the 'consensual bond' 40 required for the Court to be able to exercise jurisdiction over a state in any particular case. Contextually, a state cannot sue another state under the optional clause system, except if that state has, itself, deposited an optional clause declaration which engages that of the other state. ${ }^{41}$ The same consideration applies to the even more restrictive compromissory clauses in treaties in force and special agreements, which are limited to the specific treaty (in the case of the former) or dispute (in the case of the latter) for which this jurisdiction was given.

These jurisdictional segmentations, the rule that judgments are binding on the parties only and the attitude of states towards compliance with the dispositive part of its decisions 42 notwithstanding, the IC] establishes legal standards for states and consistently develops international law through its decisions. ${ }^{43}$ Remarkably, the advisory jurisdiction of the Court, which is generally not binding on any state, ${ }^{44}$ has made an even greater impact. ${ }^{45}$

This has also been shown to be true of decisions of the European Court of Justice $(E C J)$. Using the preliminary reference procedure of the $\mathrm{ECJ}$ as an example, it has been shown that rulings given by the

39 Electricity Company of Sofia and Bulgaria Series A/B No 77 Preliminary Objection (14 April 1939) 76 (declaring that its jurisdiction could be based on a multiplicity of agreements between states).

40 Right of Passage over Indian Territory (Portugal $v$ India) Preliminary Objections IC] Rep 1957, 125, 291 para 25.

41 Certain Norwegian Loans (France v Norway) (1957) ICJ Reports 9 23; Fisheries Jurisdiction case (Spain v Canada) (1998) ICJ Reports 423453 para 46 ('since two unilateral declarations are involved in the conferment of jurisdiction under article $36(2)$, jurisdiction is conferred upon the court only to the extent to which the declarations coincide in conferring it').

42 See AP Llamzon 'Jurisdiction and compliance in recent decisions of the International Court of Justice' (2007) 18 European Journal of International Law 815.

43 See Aegean Sea Continental Shelf (Greece $v$ Turkey) (1978) ICJ Reports 3 17-18 para 39 (acknowledging, notwithstanding art 59, that it was evident that any pronouncement of the Court may have implications in relations between states other than Greece and Turkey); separate opinion of Judge Gros in Barcelona Traction Light and Power Co Ltd (Belgium v France) Second Phase (1970) ICJ Reports 3267 para 1 (noting the 'importance of the case from the point of view of its consequences on the law applicable to international economic relations').

44 Advisory opinions are binding only when such an effect is conferred by treaty. See Part VIII, sec 30 of the Convention on the Privileges and Immunities of the United Nations (General Convention) of 13 February 19461 United Nations Treaties Series 15; Application for Review of Judgment No 158 of the United Nations Administrative Tribunal Advisory Opinion (1973) ICJ Reports 166172 para 14; Judgment of Administrative Tribunal of the ILO upon Complaints Made against UNESCO Advisory Opinion (1956) ICJ Reports 7784.

45 Examples are the Reservations to the Convention on the Prevention or Punishment of the Crime of Genocide Advisory Opinion (1951) ICJ Reports 15; Reparation for Injuries Suffered in the Service of the United Nations Advisory Opinion (1949) ICJ Reports 174 ; and so on. 
EC) are applied not only by the national court that made the reference, but also by all national courts in the EU before which the same question arises. 46

Therefore, the binding effect of a decision is one thing (this goes to the actual decision - the depositif), its authoritative effect as precedent is another (this goes to the reasoning adopted) and is much wider than its binding effect. Neither the fact that decisions are binding on the parties nor res judicata detracts from the recognition that judgments of a court 'have great bearing ${ }^{\prime 47}$ for non-parties to the case in which they were given, especially when given by a court created under an instrument that is binding as between the parties to the case and non-parties. ${ }^{48}$ While directly binding on the respondent state only, the jurisprudence of international courts have a certain contagious characteristic that reaches farther than the actual decision in a case, either through the internalisation of the interpretation adopted in the decisions into the interpreted instrument within the regime of the court and/or its eventual (albeit gradual) jurisprudential internationalisation outside the regime of the court and the interpreted instrument.

For the purpose of this discussion, the internalisation of interpretation occurs horizontally and vertically. It occurs horizontally at the level of the international court that gave the interpretation, and vertically at the level of the municipal law through case law and legislation. At the level of the international court, the interpretation may become internalised as a result of the high margin of certainty of repetition in future cases, even when the court has not had a second bite at it, ${ }^{49}$ or through consistency of application. ${ }^{50}$ Such repeated application has the ability of embedding the interpretation into the

46 FG Jacobs 'Judicial dialogue and the cross-fertilization of legal systems: The European Court of Justice' (2003) 38 Texas International Law Journal 547549.

47 Application of the Convention on the Prevention and Punishment of the Crime of Genocide (Croatia v Serbia) Preliminary Objections (2008) ICJ Reports 412435 para 71.

48 As above.

49 Croatia v Serbia (n 47 above) 429 para 54 (holding that parties cite previous decisions of the ICJ 'as precedents to be followed in comparable cases'); G Fitzmaurice 'Some problems regarding the formal sources of international law' in Symbolae Verzijl 153172 reproduced in M Koskenniemi (ed) Sources of international law (2000) 57 (noting that parties cite precedent as 'something which the tribunal cannot ignore [as] the tribunal ... will not usually feel free to ignore a relevant judicial decision').

50 Koojamas J Separate opinion in legality of use of force (Serbia and Montenegro $v$ United Kingdom) (2004) ICJ Reports 1307 1369, para 10 (declaring that '[c]onsistency is the essence of legal reasoning'). 
instrument for states within the court's regime to be binding on all parties. ${ }^{51}$ For: ${ }^{52}$

When a dispute settlement organ has been empowered to interpret authoritatively a legal regime and when its judgments become an integral part of that regime ... then its judgments necessarily have an effect erga omnes partes contractantes.

It is therefore fitting to argue that the elucidation of African Charter obligations by the African Court becomes internalised for parties to the Court Protocol to acquire a compulsory character as part of the obligations they undertook to fulfil in article 1 of the Charter. This will be easier, but not necessarily achieved through the jurisprudential integration of principles of interpretation adopted by the Court into municipal law by national courts. It also could occur through legislative incorporation where the judgment is regarded as norm creating by all state parties, to the extent that the legislature incorporates it into the state's laws by either positive acts or negative acts that acknowledge the normative quality of the interpretation. ${ }^{53}$

It is essential to acknowledge the difference between a general elucidation of African Charter obligations from one that specifically finds that a municipal law is incompatible with the Charter when considering the possibility of jurisprudential integration and in assessing its likely impact under municipal law. This must turn on the nature of the law - constitutional or legislative act - found to be incompatible with the Charter and the sphere - national or international - in which the issue is raised. For incompatibility involving ordinary legislation, it appears that the law of many state parties to the African Court Protocol has a general direction towards allowing municipal courts to rely on interpretations of the African Court to trump the incompatible legislation either by clear constitutional provisions $^{54}$ or by precedent. $^{55}$ When it involves

51 R Flamini 'Judicial reach: The ever-expanding European Court of Justice' (2012) 175 World Affairs 55 (observing that 'once the existence of the court is recognised by the member states, its decisions must be as well').

52 CPR Romano 'The proliferation of international judicial bodies: Pieces of the puzzle' (1998-1999) 31 New York University Journal of International Law and Politics 709737.

53 P Tangney 'The new internationalism: The cession of sovereign competences to supranational organisations and constitutional change in the United States and Germany' (1996) 21 Yale Journal of International Law 395406 (suggesting that the EC) plays a prominent role in interpreting and enforcing the treaties because 'all member states accept that ... ECJ opinions ... are supreme and trump any conflicting national legal provisions').

54 The constitutions of some member tates give applicable treaties a status superior to ordinary legislations; art 87 of the Constitution of Côte d'Ivoire 2000; art 190 the Constitution of Rwanda 2003; and so on.

55 In Nigeria, the Constitution is silent on the status of incorporated treaties vis-à-vis legislative acts. However, in Abacha v Fawehinmi [2001] 1 NWLR (Pt 662) 228289 , the Nigerian Supreme Court held that the legislation by which the Charter was incorporated into Nigeria 'is a statute with international flavour', which must trump any other statute except the Constitution, and that the Charter possesses ' $a$ greater vigour and strength' than any other domestic statute. 
constitutional incompatibility, jurisprudential integration is inconceivable, ${ }^{56}$ and only legislative incorporation can give effect to the incompatibility ruling as this entails constitutional amendment.

From the viewpoint of international law, however, it does not matter what law is incompatible. The result is the same - the state is duty-bound to bring its laws in sync with its international obligation by eliminating the incompatibility. ${ }^{57}$

Internalisation beyond the court's or an instrument's regime occurs, not on the basis of any obligation, but on the sheer strength of persuasion that a decision possesses. This is in addition to the general tendency of courts and lawyers to enrich judicial reasoning with solutions adopted elsewhere through the process of "judicial dialogue and cross-fertilisation'. ${ }^{58}$ This also has both horizontal and vertical aspects.

The vertical aspect occurs either through the cascading of the principle to national systems through the regime of another international court or through the incorporation of the principle into their legal orders by national courts. Thus, national courts or even states outside the regime of a court and the instrument being interpreted may be influenced by the 'legal credibility' 59 of the interpretation to adopt the interpretation as the correct interpretation of the instrument or similar instrument (as the case may be) in their domestic and diplomatic dealings.

On the other hand, the horizontal aspect arises by the acceptance of the interpretation as authoritative by other international courts whether or not they share competence over the same instrument. In the Tanganyika case, the African Court relied on the persuasive force of cases decided by the European Court and the Inter-American Court on the European Convention on Human Rights and Fundamental Freedoms of 1950, and the American Convention on Human Rights of 1969, to which the parties to its Protocol are by no means connected. ${ }^{60}$ In Interights, ASADHO \& Disu $v$ Democratic Republic of Congo, ${ }^{61}$ the African Commission internalised and applied a principle

56 Some constitutions expressly require constitutional amendment for constitutionally-incompatible international law to be effective municipally; art 86 of the Constitution of Côte d'Ivoire; art 79 of the Mauritanian Constitution; etc. Other constitutions achieve this effect indirectly by their supremacy clause; sec 1(2) of the Ghanaian Constitution 1992; sec 4 of the Gambian Constitution 2002.

57 Treatment of Polish Nationals, PCIJ series A/B 4424 (holding that a state cannot adduce as against another state its own constitution to evade its treaty obligations).

58 Jacobs (n 46 above) 556.

59 Joint Declaration of Vice-President Renjeva, Guillaume, Higgins, Kooijmans, Al-Khasawneh, Buergenthal and Elaraby JJ in Legality of use of force (n 50 above) 1356 para 12.

60 See part III above; also, citing the Australia case of Commonwealth $v$ Tasmania (1983) 158 CLR 1; Jacobs (n 46 above) 549 (demonstrating that ECJ rulings have an influence on courts outside the EU).

61 Communications $274 / 03 \& 282 / 03$. 
adopted by the ECOWAS Court on the right to liberty to a case involving the Republic of Congo, ${ }^{62}$ which is not even entitled to ratify the ECCJ Protocol, let alone anticipate proceedings before the Court.

It is fitting to expect that decisions of the African Court would serve as interpretative notice to such regional courts as the ECCJ and East African Court of Justice (EACJ), ${ }^{63}$ which interpret the African Charter 64 with, arguably, more jurisdictional strength over their respective community members than the African Court has over AU members. ${ }^{65}$ Essentially, these courts could internalise the interpretation adopted by the African Court and, once that occurs, such interpretation achieves its potential for a wider application.

Account is also taken of the fact that the African Charter gives parties no choice on the jurisdiction of the African Commission. As a result, interpretations adopted by the African Court are potentially applicable to all parties to the Charter through the Commission. Although the jurisprudential relationship between the African Commission and African Court is still developing, it is expected that the Commission would defer to the jurisprudence of the Court.

Drawing from the foregoing, decisions of the African Court, as a judicial institution of the $A U$, are able to have implications beyond the states that are directly bound by them, to affect all state parties to the African Charter, whether or not they are also parties to the Protocol of the African Court. It is, therefore, possible for a finding of incompatibility made by the Court to benefit from a wider application as an authoritative interpretation of the Charter. It may be gathered from what has been said above that it is only a matter of degree; the effect the Court's authoritative interpretation of the Charter should have on parties to both the Charter and its Protocol as distinguished from parties to the Charter only. This is so when considered alongside article $3(\mathrm{~h})$ of the Constitutive Act of the AU, to which all state parties to the African Charter are also parties. Under article 3(h), state parties undertook to 'promote and protect human and peoples' rights in accordance with the African Charter'. It is thus possible to argue that it is part of the role of the African Court, as an institution set up by the

$62 \mathrm{n} 61$ above para 70 (the principle was that adopted in ECW/CCJ/APP/04/07 Manneh $v$ The Gambia).

63 Art 9 of the Treaty for the Establishment of the East African Community of 30 November 1999, as amended in 2006 and 2007. Though yet to have human rights jurisdiction due to arts 27(1) and (2), it has been exercising that jurisdiction indirectly; Emmanuel Mjawasi \& Others $v$ The Attorney-General of the Republic of Kenya, Reference 2, judgment of 28 September 2011. See also A Possi 'Striking a balance between community norms and human rights: The continuing struggle of the East African Court of Justice' (2015) 15 African Human Rights Law Journal 192.

64 Both courts apply the African Charter: See art 4(g) of ECOWAS Revised Treaty of 24 July 1993, which incorporates the African Charter into the Revised Treaty of ECOWAS by reference. See SERAP v Federal Republic of Nigeria and Universal Basic Education Commission ECW/CCJ/APP/08/08 para 28; Plaxeda Rugumba v SecretaryGeneral of the EAC \& Attorney-General of Rwanda, Ref 8 of 2010 EACJ para 23.

65 They are the judicial organs of their respective communities to which individuals have unimpeded access. 
$\mathrm{AU}$ for the purpose of assisting states to fulfil their obligations, to protect the fundamental human rights enshrined in the Constitutive Act of the AU. ${ }^{66}$ The African Court cannot but be, at least from the viewpoint of the $A U$, the final authority in the interpretation of the African Charter. ${ }^{67}$

This appears quite an expected outcome. For Mutua, the Court should seek to expound on the Charter and make law that would guide African states in developing legal and political cultures that respect human rights by creating a body of law with precedential value to guide and deter African states from future misconduct by modifying their behaviour. ${ }^{68}$ Oder also believes that '[t]he African Court's judgments will have a wider impact, beyond the country against whom an application has been brought ${ }^{\prime} .69$

The obligation to cure the incompatibility found to exist by the African Court in the Tanganyika case should, therefore, not be viewed as an obligation limited to Tanzania. The case has latent obligatory jurisprudential ramifications for all parties to the African Court Protocol while, at the same time, it is capable of influencing non-state parties to the Protocol who are parties to the African Charter and the Constitutive Act.

In taking a broad view of the uniform application of interpretations adopted by the African Court, account is taken of the fact that the African Commission had variously made incompatibility findings which did not have the effects envisaged here. ${ }^{70}$

Without being overly dismissive, the recommendations of the African Commission were never designed to have a direct effect on the behaviour of state parties. ${ }^{71}$ This is so because the Commission is 'a quasi-judicial body with no binding powers' ${ }^{72}$ and which addresses

66 See Plaxeda Rugumba (n 64 above) para 23.

67 This is not to say that the Court could sit on appeal over a matter already decided by any other regional court in Africa. See Mtingwi v Malawi (n 25 above).

68 Mutua, (n 6 above) 362.

69 J Oder 'The African Court on Human and Peoples' Rights' order in respect of the situation in Libya: A watershed in the regional protection of human rights?' (2011) 11 African Human Rights Law Journal 495506.

70 See Purohit \& Another v The Gambia (2003) AHRLR 96 (ACHPR 2003); Scanlen v Zimbabwe (n 27 above) para 125.

71 G Bekker 'The African Court on Human and Peoples' Rights: Safeguarding the interests of African States' (2007) 51 Journal of African Law 151171.

72 Romano (n 52 above) 721. Also see EG Nalbandian 'The challenges facing the African Court of Human and Peoples' Rights' (2007) 1 Mizan Law Review 75 88; F Viljoen \& L Louw 'State compliance with the recommendations of the African Commission on Human and Peoples' Rights 1994-2004' (2007) 101 American Journal of International Law 12 (noting that the Commission is 'a quasi-judicial supervisory body'). 
its recommendations to the Assembly of Heads of State and Government. $^{73}$ Its recommendations are thus in a different position to decisions of the African Court in that the latter have the force of finality, and this greatly enhances their ability to integrate into the African Charter regime in comparison to that of the Commission. ${ }^{74}$

\section{Practical difficulties}

The hope that the African Court could promote an African-wide human rights standard through its jurisprudence may be hampered by several difficulties discussed below.

\subsection{Limited ratification/optional declaration}

Since the African Court is established for the purpose of enhancing the safeguards of the African Charter, its jurisdictional reach ought to be as far-reaching as the Charter itself, so that no state party to the Charter is exempt from the jurisdiction of the Court. If this had been achieved, decisions of the Court on incompatibility against a state should serve as notice to all other state parties that they must abolish similar legislation to resolve the incompatibility and so bring their laws in sync with the decisions of the Court. Although they cannot be affected by decisions to which they were not parties, it is sufficient that the African Court would take a similar view of their own legislation when brought before the Court, and this would be a costlier choice for states.

A major difficulty, one that would continue to plague the African Court, therefore, is the fact that it cannot exercise any form of jurisdiction over many of the parties to the Charter because of their failure to ratify its Protocol as '[a] treaty does not create either obligations or rights for a third state without its consent'. ${ }^{75}$ This would mean that the Tanganyika case does not put duties on Zambia and Sierra Leone that prohibit independent candidacy because they are yet to ratify the African Court Protocol.

73 See N Enonchong 'The African Charter on Human and Peoples' Rights: Effective remedies in domestic law?' (2002) 46 Journal of African Law 197 (arguing that the Assembly of Heads of State and Government, to which the Commission submits its recommendations, cannot convert the recommendations into binding decisions).

74 CS Martorana 'The new African Union: Will it promote enforcement of the decisions of the African Court on Human and Peoples' Rights?' (2009) 40 George Washington International Law Review 583599 (noting that 'because the absence of an enforcement provision in the Charter was arguably its greatest weakness, the [African Court] Protocol's provision for binding orders shows the greatest promise').

75 Art 34 of the VCLT; JI Charney 'Universal international law' (1993) 87 American Journal of International Law 529534 (declaring that '[c]learly, its consent is required before a state is bound by treaty obligations. The state must accept such an obligation voluntarily ... Third states cannot be bound by treaty obligations without their consent.') 
Even for states that have ratified the African Court Protocol, the reach of decisions of the Court as precedent in comparable cases is rendered almost non-existent by the restriction on the access of individuals as a result of the failure of states to make the optional declaration. This limits the chances of the Court of reaffirming the decision against Nigeria.

There is, however, the possibility of judicial application of the case to Nigeria and Sierra Leone by the ECCJ and Zambia by the EACJ at the instance of individuals.

Failing application at the instance of individuals, there remains the unlikely event of another state party suing either as an interested party, for the purpose of enhancing the safeguards of the African Charter across all state parties in fulfilment of the reciprocal obligations of state parties, or in the exercise of its right to diplomatic protection. This could be through the African Commission. ${ }^{76}$ However, as has been observed, '[b]oth these mechanisms have so far languished in desuetude' because African states are unwilling to bring human rights claims against another African state and, except for three cases, ${ }^{77}$ the Commission is generally unwilling to refer cases to the African Court. ${ }^{78}$ Remarkably, the only case that has been finalised of the three cases brought by the Commission was dismissed for a lack of diligent prosecution. ${ }^{79}$

\subsection{Norm of a different order}

From the viewpoint of international law and, more so, from that of municipal law, the African Court, as it stands, belongs to a completely different order to the municipal order of member states. ${ }^{80}$ As a result, the finality of the Court's decisions 81 and the undertaking by state

76 D Juma 'Provisional measures under the African human rights system: The African Court's order against Libya' (2012-2013) 30 Wisconsin International Law Journal 344350 (noting that in view of the 'qualified access of individuals and nongovernmental organisations, the African Commission is currently the main pathway to the African Court').

77 Application 004/2011 African Commission on Human and Peoples' Rights v Great Socialists Republic of Libyan Arab Jamahiriya; Application 006/2012 African Commission on Human and Peoples' Rights v Kenya; Application 002/2013 African Commission on Human and Peoples' Rights v Libya. See generally Juma (n 76 above)

78 CC Jalloh 'Michelot Yogogombaye v Republic of Senegal' (2010) 104 American Journal of International Law 620624.

79 African Commission on Human and Peoples' Rights v Libyan Arab Jamahiriya (n 77 above) para 26(b) (noting that the applicant failed to pursue the application).

80 A Stemmet 'A future African Court for Human and Peoples' Rights' (1998) 23 South African Yearbook of International Law 233235 (noting that '[b]y becoming party to an international instrument creating a supra-national tribunal, states accede to the establishment of a new level of jurisdiction'); San Michele $v$ High Authority 4 Judgment 98 1965, cited in ML Volcansek 'Impact of judicial policies in the European Community: The Italian Constitutional Court and European community law' (1989) 42 The Western Political Quarterly 575, wherein the Italian Constitutional Court recognised two jurisdictions: one Italian and another EU, 'whose organs are admittedly placed in separate juridical spheres'. 
parties to comply with its decisions, are insufficient to translate them into enforceable court decisions within the normative order of member states, nor will its judicial powers as an international court necessarily induce compliance under municipal law. In other words, although engaging the international responsibilities of member states, the binding nature of the decision of an international court alone does not lead to compliance. ${ }^{82}$

This duality has consequences for states that have ratified the African Court Protocol and made the optional declaration as they still have to surmount the practical difficulties that are naturally attendant upon the translation of international norms into legally-enforceable municipal norms. These difficulties are even more pronounced when an obligation seeking municipal enforcement arises from the decision of an international court that challenges a municipal legal status quo, predicated on a constitutional instrument. This is more so when the treaty establishing the African Court lacks a clearly-defined municipal application, and this invariably means that the Court, itself, is in need of a defined municipal status. The implications of this are far-reaching; first, for the enforcement of the decisions of the Court within municipal legal systems and, second, to the capacity of the interpretation of the African Charter by the Court to command the positive responses of the organs of member states, whether or not they were also parties to the proceedings in which the interpretation was given. 83

In the emerging international legal regime of the $A U$, given that there is no legal correlation between the African Court and the legal systems of state parties, the relevant questions a national judge may ask when prayed to enforce a judgment of the African Court or to take account of its precedent are the following: Is the African Court Protocol recognised under our laws? ${ }^{84}$ Am I under any obligation to take account of the judgments or jurisprudence of the African Court?

If these questions are answered in the negative, the municipal court would decline jurisdiction. In at least two cases, decisions of the ICJ have been discountenanced by municipal courts on the ground that article 94 of the UN Charter, in terms of which state parties to the

81 Art 28(2) African Court Protocol.

82 Juma (n 76 above) 351.

83 Volcansek (n 80 above) 569583 (arguing that '[t]he legitimacy accorded to community law is directly related to the level of compliance in a national judicial system'); Possi (n 63 above) 202 (arguing that '[i]nternational judges ... are more likely to become expansionist law makers where they are supported by interlocutors and compliance constituencies, including government officials, advocacy networks, national judges and administrative agencies').

84 F Viljoen 'Application of the African Charter on Human and Peoples' Rights by domestic courts in Africa' (1999) 43 Journal of African Law 1 (noting that '[i]t is unlikely that judicial institutions will make findings based on the provisions of the African Charter if the Charter is not regarded as part of domestic law'). The same principle applies to the African Court Protocol; it requires domestic status to properly function within the legal systems of member states. 
Charter undertook to enforce the judgment of the $[\mathrm{CJ}$, was not domestically applicable in the forum states. ${ }^{85}$

This undefined municipal legal status of the African Court creates a legitimacy problem and an obstacle to the acceptance of its decisions, ${ }^{86}$ as well as 'dilute[s] or weaken[s] the[ir] effect', ${ }^{87}$ especially in cases of the nature being discussed where a decision of the Court conflicts with municipal law of a constitutional status. The typical response of state parties, as already indicated by Tanzania in its response to the judgment in Tanganyika Law Society, 88 is that the judgment of the Court is wrong because it runs contrary to prevailing municipal law. ${ }^{89}$ It is illusory to assume that national judges would reason otherwise, especially in the Court's present state of development ${ }^{90}$ and the limited ratification of its Protocol by the signatory states.

One way of surmounting this problem is by demonstrating a clear willingness to imbue the Court 'with unparallelled transnational power $^{\prime 91}$ in African Charter affairs, both in theory and in practice, and in recognition of the competence ceded to the Court. ${ }^{92}$ It is thus

85 The United States Supreme Court case of Jose Ernesto Medellin v Texas (2008) 128 Supreme Court Reporter 1346 (refusing to respect the decision of the IC) in Avena and Other Mexican Nationals (Mexico v United States of America) (2004) ICJ Reports 1236 para 40); the Italian Constitutional Court case of Repubblica Italiana in Nome Del Popolo Italiano or Italian Republic in the Name of the Italian People Italian Constitutional Court Judgment 238/2014. This English summary of the judgment was provided by Francesco Messineo in https://dl.dropboxusercontent.com/u/ 39082100/Italian\%20Constitutional\%20Court\%20Judgment\%20238-2014.pdf (accessed 10 October 2014) (refusing to respect Jurisdictional Immunities of the State (Germany v Italy, Greece Intervening) (2012) ICJ Reports 99); the Ghanaian Supreme Court case of Republic v High Court (Commercial Division) Accra, Ex parte Attorney-General Civil Motion J5/10/2013 (Supreme Court, Ghana, 2013), http:// www.pca-cpa.org/Supreme\%20Court\%20Decision9703.pdf?fil_id=2336

(accessed 24 January 2016) (refusing to enforce a decision of the International Tribunal for the Law of the Sea because the United Nations Convention on the Law of the Sea is not domestically applicable in Ghana).

86 Volcansek (n 80 above) 583 (arguing that '[l]egitimacy of law and of the law-giver go far in explaining why and how policies are implemented by courts').

87 Lord Bingham of Cornhill in $R \mathbf{v}$ Special Adjudicator (Respondent) ex parte Ullah (FC) (Appellant) [2004] UKHL 26 para 20.

88 n 4 above.

89 Application 011 of 2011 Rev Mtikila v Tanzania Ruling on Reparation para 43.

90 In Solange I, decision of 29 May 197437 BVerfGE 271 [1974] CMLR 540, the German Constitutional Court ruled that '[a]s long as the integration process has not progressed so far that community law also receives a catalogue of fundamental rights ... of settled validity, which is adequate in comparison with the catalogue of fundamental rights contained in the [German] Constitution', it would decide for itself whether community law would be supreme. This position was subsequently abandoned by the Court in Solange II, decision of 22 October 1986 73 BVerfGE 339378 (holding that EC) had achieved a certain minimum quantity of protection of basic rights and had developed sufficient institutional architecture through case law for the protection of individual rights).

91 Flamini (n 51 above) 55.

92 P Kelly 'The International Court of Justice: Crisis and reformation' (1987) 12 Yale Journal International Law 342343 (stating that 'the acceptance of compulsory jurisdiction requires the surrender of an element of sovereignty'). 
essential for state parties to be prepared to adopt legislative reforms ${ }^{93}$ to remove constitutional impediments to the ability of the Court to thrive. State parties may enact legislation directing municipal courts to take decisions of the Court into account in matters relating to its competence $^{94}$ in the absence of strong reasons to act otherwise. This would also mean a clear obligation that 'primary and subordinate legislation must be read and given effect in a way that is compatible' 95 with the standard set by the Court, as far as it is possible to do so, and that the legislature is itself prepared to legislatively support a supranational interpretation of the African Charter, including changing the law to conform to standards established by the Court, as far as it is possible to do so.

It is worth mentioning that some legal grounds already exist that may be explored by national courts to follow decisions of the African Court in some African states, such as South Africa and Tanzania. Section 233 of the Constitution of South Africa directs courts, when interpreting any legislation, to prefer any reasonable interpretation that is consistent with international law over any alternative interpretation that is inconsistent with international law. In Tanzania, the courts are mandated to construe existing law 'as may be necessary to bring it into conformity with' the provisions of the Bill of Rights. ${ }^{96}$ Based on this provision, the African Charter has been held to be included in the Bill of Rights of which courts are to take cognisance. ${ }^{97}$ These provisions are, to some extent, comparable to article 2 of the United Kingdom's Human Rights Act of 1988, under which '[a] court or tribunal determining a question which has arisen in connection with a European Convention right must take into account any ... judgment' of the European Court of Human Rights. Drawing from the differences of opinion on the true import of this provision on the weight to be accorded to judgments of the European Court by courts in the United Kingdom, ${ }^{98}$ it is difficult to be very optimistic that South African ${ }^{99}$ and Tanzanian courts would interpret the relevant provision

93 Exchange of Greek and Turkish Populations Advisory Opinion PCIJ Ser B 10, 20 (the $\mathrm{PCI}$ recalling the 'self-evident' principle, 'according to which a state which has contracted valid international obligations is bound to make in its legislation such modifications as may be necessary to ensure the fulfilment of the obligations undertaken').

94 See RKM Smith 'Notes' (2003) 97 The American Journal of International Law 664 664 for insights into the relationship between judgments of the ECJ and UK courts following the entry into force of the UK Human Rights Act 1998.

95 As above.

96 Sec 5(1) of the Constitution (Consequential, Transitional and Temporal Provisions) Act 16 of 1984, which took effect in March 1988.

97 DPP v Pete [1991] LRC (Const) 553565 cited in Viljoen (n 84 above) 14.

98 See 'The UK and the European Court of Human Rights' (2012) 83 Equality and Human Rights Commission Research Report 115.

99 It is worth reiterating that occasions for South African courts to interact with decisions of the African Court are limited by its failure to make the requisite declaration to permit individuals to bring claims against it at the Court. 
in favour of the supremacy of the decision of the African Court over established municipal law positions.

\subsection{Unsettling municipal jurisprudence}

There is also the difficulty that arises from the fact that the African Charter, having long been given effect to within the municipal realm of state parties, may already have acquired certain settled case law which may be narrower than, and incongruous to, the interpretation the African Court adopts. The interpretation under municipal law of the African Charter, being only an 'element in the mosaic of different constitutional provisions' 100 within the domestic legal order of state parties, influenced by local circumstances, may differ considerably from an interpretation based on the Charter alone. ${ }^{101}$ No doubt problems would arise if 'a higher level of protection were to be established by the Court, or if it should strike balances between competing rights that differ from those established by the domestic courts'. 102

This possibility heightens the potential for conflict between the courts of the two spheres ${ }^{103}$ and creates a defensive and repulsive altitude on the part of national courts. Backed by the principle of sovereignty and constitutional supremacy, national courts, except by clear legal authorisation, would naturally defer to local statutes and maintain the established case law, ${ }^{104}$ particularly where the case law implements a constitutional provision or where the jurisprudence of the international court ruptures the constitutional division of power. 105

The obstinate posture of national courts over constitutional matters is, understandably, quite commonly shared by all legal systems. The fact is that states as well as their judiciaries dislike being told what to do by an international judicial body. The success rate of the European Court of Justice and the European Court of Human Rights

$100 \mathrm{G}$ Ress 'The effect of decisions and judgments of the European Court of Human Rights in the domestic legal order' (2005) 40 Texas International law Journal 359 376.

101 As above.

102 Stemmet (n 80 above) 236.

103 Stemmet 235 (arguing that the 'the creation of a supra-national legal system inevitably carries the seeds of possible conflict with domestic legal systems').

104 As above.

105 Tangney (n 53 above) 397 (arguing that '[t]he judiciary is the final bulwark against fundamental revisions of the constitution outside the amendment process and that the judiciary ensures that separation of powers is protected and that no competences necessary for the judiciary and legislature to perform their constitutional roles are delegated'). 
notwithstanding, opposition against the intrusive effects of their judgments in the municipal realm of member states is still evident. 106 In this regard, Lord Hoffmann once noted that there was something fundamentally wrong with an international court seeking to impose common solutions on national legal systems. Arguing that it was a basic flaw, he questioned 'the concept of having an international court of human rights to deal with the concrete application of those [human] rights in different countries'.107 To Hoffmann, 'unlike the Supreme Court of the United States or the supreme courts of other countries performing a similar role, the [European Court of Human Rights] lacks constitutional legitimacy'.

It is nonetheless important for state parties to come to terms with the fact that the African Court is an international court having the competence to apply the African Charter in its treaty character, free from the influences that limit its application within their municipal spheres. The African Court is neither bound by the narrow interpretation of Charter rights by municipal courts, nor can it be expected that it would adopt an interpretation narrower than the interpretation of municipal courts. It has a duty to maintain the 'basic premise of international human rights law [which] is that certain standards must be constant across national borders, and governments must be held accountable to these standards' ${ }^{109}$ It is thus incumbent on municipal courts to align their case law with the jurisprudence of the African Court on articles of the African Charter with a view to a broad and consistent application of the Charter across national boundaries. ${ }^{110}$ Municipal courts should accept the 'powerful logic in saying that authoritative interpretations of ... [Charter] rights by the ... [African Court] should generally be treated as authoritative in the domestic legal system as well'. ${ }^{111}$

106 See LL Hoffmann 'The universality of human rights', Judicial Studies Board Annual Lecture, London, 19 March 2009 para 24 (noting that the member states of the Council of Europe did not subscribe to uniformity of the application of the abstract rules of human rights in each of their countries); Repubblica Italiana in Nome Del Popolo Italiano (n 85 above) 24 para 2 (affirming the court's constitutional obligation to determine the compatibility of laws with the Constitution).

107 Hoffmann (n 106 above) para 25.

108 Hoffmann para 38.

109 Constitutional Rights Project \& Another v Nigeria (2000) AHRLR 191 (ACHPR 1998) para 48

110 G Martinico 'Is the European Convention going to be "supreme"? A comparative constitutional overview of ECHR and EU law before national courts' (2012) 23 European Journal of International Law 401409 (noting that '[m]ore generally, consistent interpretation is a typical doctrine of multilevel systems').

111 P Sales 'Strasbourg jurisprudence and the Human Rights Act: A response to Lord Irvine' (2012) 2 Public Law 253 261-262. 
Otherwise, as Nwauche noted about the possibility of there being as many as 15 national interpretations of ECOWAS law and the African Charter by the courts of the 15 states making up ECOWAS, ${ }^{112}$ we would be having such variations across the 53 state parties to the Charter. The fact, for instance, that the 1999 Nigerian Constitution does not protect socio-economic and cultural rights, ${ }^{113}$ which are protected by both the Ghanaian Constitution of 1992 and the African Charter, is a direct pointer to the prevalence of national variations were national courts and constitutions to be the controlling factors. ${ }^{114}$

Having agreed to the African Charter, irrespective of the fact that it exemplifies 'a case where regional standards have been set above existing individual domestic standards' ${ }^{115}$ it is unacceptable for the parties to seek to narrow its application to them by constitutionally excluding the enforceability of Charter rights.

The actualisation of the cession of the competence of finality to an international court in practice does not come easily, as municipal institutions and political actors often find it difficult to accept what may be perceived as an overbearing interpretation of an international instrument by an international court. Nevertheless, resistance, such as already indicated by Tanzania, ${ }^{116}$ to a competence already granted by state parties to an international court is a function of the initial shock that judicial institutions and political actors need to absolve in an emerging system which permits an international court to hold national governments accountable.

\subsection{The local circumstances factor}

There is also the difficulty that arises from the local circumstances that prevail in different states and which highlight the peculiarities of each of them. These circumstances may arise in the form of peculiar legal traditions, religious orientations, cultural, ethnic and historical diversities, stages of economic, and social and democratic developments, among others.

The need to take local circumstances into account when deciding on whether to follow what municipal actors may consider an overstated ratio of an international human rights court is commonly shared by supranational legal systems. This has severally resonated in decisions of courts of the United Kingdom in relation to the European Court. The European Court, for its part, understands that there is a

112 ES Nwauche 'The ECOWAS Community Court of Justice and the horizontal application of human rights' (2013) 13 African Human Rights Law Journal 36.

113 See SERAP v Federal Republic of Nigeria (n 64 above), where the ECC) held Nigeria bound by socio-economic rights, notwithstanding that they are non-justiciable under the Nigerian Constitution.

114 See Nwauche (n 112) 36.

115 AB Akinyemi 'The African Charter on Human and Peoples' Rights: An overview' (1985) 46 The Indian Journal of Political Science 208238.

116 Mtikila v Tanzania (Reparation) (n 89 above). 
certain 'margin of appreciation'117 that should be allowed to municipal courts.

In $R$ (on the Application of Alconbury Developments Ltd) $v$ Secretary of State for the Environment, Transport and the Regions, ${ }^{118}$ Lord Slynn declared that domestic courts should follow the 'clear and constant' jurisprudence of the European Court, but that it should do so only 'in the absence of some special circumstances'. In the same case, Lord Hoffmann doubted whether a decision of the European Court, which led to a result that was 'fundamentally at odds with the distribution of powers under the British Constitution', should be followed. ${ }^{119}$ For Lord Mance, section 2 of the Human Rights Act of 1998, which requires English courts to 'take into account' European Court decisions, cannot be the basis for following decisions that are inconsistent with some fundamental substantive or procedural aspect of English law, and which reasoning appears to overlook or misunderstand some arguments or point of principle of English law. ${ }^{120}$ In another case, Lord Philips said that, although the requirement to 'take into account' the European Court jurisprudence would 'normally result' in the domestic court applying principles that are clearly established by the European Court, there would be occasions where the domestic court has concerns as to whether a decision of the European Court sufficiently appreciates or accommodates particular aspects of the domestic process. In such circumstances, Lord Philips would allow domestic courts to decline to follow the decision and give reasons for the refusal, as this is likely to give the European Court the opportunity to reconsider the particular aspect of the decision that is in issue, 'so that there takes place what may prove to be valuable dialogue' between domestic courts and the European Court. ${ }^{121}$

Local circumstances thus may justify the adoption of certain laws by the legislature or certain case law by national courts which, taken in isolation, could be said not to be in conformity with African Charter obligations. Thus, in order to correct inequalities among the ethnic or geographical divisions of its population, a state may adopt laws to favour some groups over others, to make it easier for the favoured groups to gain employment or school placements than the other groups. Municipal courts may also skew its case law in the same direction. While this, in itself, results in unequal treatment, it may be justified by the local circumstances of a state where the favoured

117 Stemmet (n 80 above) 242 (noting that the principle of the margin of appreciation was developed by the European Court and the European Commission of Human Rights to allow the domestic legal systems and the European Convention to coexist without undue tension).

118 [2003] 2 AC 295 para 26.

$119 R \vee$ Secretary of State (n 118 above) para 76; $R \vee$ Horncastle [2010] 2 AC 373; [2009] UKSC 14.

120 Doherty $v$ Birmingham City Council [2009] 1 AC 367 para 126.

$121 R v$ Horncastle (n 119 above) para 11. 
group had suffered segregation over a long period of time but not in another where there has not been a similar experience. 'Local circumstances' is, therefore, a strong factor that may affect a uniform interpretation of the African Charter, and it is one that the African Court cannot simply ignore without backlashes. The African Court should therefore be careful not to treat every objection by states' organs as a battle-line, without seeking to understand the local circumstances behind a particular law, insofar as the law does not seek to 'override ... or undermine fundamental rights guaranteed by ... the Charter'. ${ }^{122}$ Where an alternative exists, the African Court should avoid 'a ruling [that] could throw the domestic human rights regime into disarray ${ }^{\prime 23}$ at the complaint of an individual if the regime works well for the majority and for the peace and unity of the state.

The aim of a system-wide approach should, therefore, be that of complementarity and dialogue and not of subordination of national courts to the African Court. Jealous of their jurisdiction, national courts would denounce an international system they consider to be in competition with national jurisdiction. As another writer puts it, ' $[\mathrm{t}] \mathrm{he}$ more acceptance that judges at the national level perceive about their own place in political power sharing, the more likely they are to implement transnational norms ${ }^{\prime}{ }^{124} \mathrm{It}$ is therefore essential to forge a healthy partnership that allows national courts some liberty to refuse to follow the jurisprudence of the African Court with reasons after 'taking account' of it. Such refusal should be a form of feedback mechanism to the Court and an invitation for a reconsideration of its established standard in the light of the objections raised by municipal courts. In $R \vee$ Horncastle, ${ }^{125}$ the refusal of both the British Court of Appeal ${ }^{126}$ and the Supreme Court to follow the jurisprudence of the Chamber of the European Court in Al-Khawaje \& Tahery $v$ United Kingdom, ${ }^{127}$ goaded the Grand Chamber of the Court to robustly reconsider the aspect of the decision that was in issue in AlKhawaja. ${ }^{28}$

It is only through this kind of dialogue and feedback that the African Court can, in partnership with national courts, develop consensus towards a uniform human rights standard for the continent. In gradually building consensus, however, the Court must not let itself be cowed into allowing the interests of states and the initial resistance of municipal courts to determine its jurisprudential directions. After all, it was such initial resistance that gave the European Court the opportunity to proclaim the supremacy of EU

122 Media Rights Agenda \& Others v Nigeria (2000) AHRLR 200 (ACHPR 1998) para 64.

123 Stemmet (n 80 above) 235.

124 Volcansek, (n 80 above) 583.

125 n 119 above.

126 [2009] EWCA Crim 964.

127 (2009) 49 EHRR.

128 Applications 26766/05 \& 22228/06. 
laws in Costa $\vee E N E L,{ }^{129}$ where the initial negative posture of the Italian Constitutional Court towards EU treaties led the ECJ to proclaim that the European Economic Council (now the EU) Treaty was 'an integral part of the legal system of the member states' and embodied laws that 'could not ... be overridden by domestic legal provisions'. 130

The African Court will particularly have to stand its ground if it were to reverse certain relics of established African cultural ethos, such as the subjugation of the rights of women, which still reflects in municipal laws across African states. It is hoped that the African Court would develop an acceptable model of relationship that would further its purpose without placing itself at the mercy of national preferences or making itself too alien to 'customs generally accepted as law, general principles of law recognised by African states as well as legal precedents and doctrine'. ${ }^{131}$ It should exercise its mandate to develop 'a truly African conception of human rights and an African human rights jurisprudence ${ }^{132}$ in a way that respects and preserves the morality of African society. The Court cannot simply 'copy and paste' the jurisprudence of the European and the Inter-American systems and expect its decisions to be well received.

\subsection{Claw-back clauses}

Claw-back clauses are provisions in the African Charter that permit member states to enact rules and regulations limiting or setting conditions for the enjoyment of the rights safeguarded by the Charter. ${ }^{133}$ They are formulated in the Charter in such phrases as 'except for reasons and conditions previously laid down by law'; ${ }^{134}$ 'necessary restrictions provided for by law'; ${ }^{35}$ 'subject to law and order'; ${ }^{136}$ 'within the law'; ${ }^{137}$ and so forth.

Although the desirability of these clauses often has been questioned and fears expressed that they 'permeate the African Charter and permit African states to restrict basic human rights to the maximum extent allowed by domestic law', 138 the local circumstances factor, it would appear, is the purpose that the 'claw-back clauses' in the Charter are designed to serve, if kept within defined limits. This is because they do have the merit of allowing the African Court to appreciate and respect a certain domain of sovereign competence by

129 Case 6/64 Costa v ENEL [1964] 3 CMLR 425; ECR 585.

130 Costa (n 129 above) 593.

131 Stemmet (n 80 above) 240 (urging the African Court to follow the example of the ECJ by minimising a possible conflict with the widely-divergent domestic legal orders of state parties).

132 Bekker (n 71 above)157.

133 Martorana (n 74 above) 596.

134 Art 6.

135 Art 11

136 Art 8.

137 Art 9. 
which a member state could regulate its affairs. They could, therefore, serve as tension absolvers and may have enhanced the willingness of African states to participate in the African Charter regime. Its usage, if it is such as to render a Charter right non-existent or to set onerous conditions for its enjoyment by states, should be struck down by the African Court as a violation of the Charter.

The African Commission has always set limits to claw-back legislation. The Commission had declared that claw-back clauses should not serve the purpose of a general restriction on rights, as this would 'diminish public confidence in the rule of law and are often counter-productive'; ${ }^{139}$ also that '[n]o situation [not even a claw-back clause] justifies the wholesale violation of human rights'. ${ }^{140}$ In Scanlen $\&$ Holderness $\vee$ Zimbabwe, the Commission declared that the phrase 'within the law' required a consideration of 'whether the restrictions meet the legitimate interests, and are necessary in a democratic society', 141 and that the phrase 'within the law' as 'employed in the Charter cannot be divorced from the general concept of the protection of human rights and freedoms'.142 In totality, however expressed in the African Charter, the Commission has established that claw-back clauses cannot derogate from the overall obligations of member states under the Charter. ${ }^{143}$

Nevertheless, the presence of claw-back clauses in the African Charter is a clear invitation to state parties to give effect to the rights in respect whereof derogation is permitted in a manner that suits their national interests and local circumstances. It may therefore be possible that no two claw-back legislations adopted by states to regulate the same right in the Charter are the same, although they serve the same end of regulating the exercise of the right contained in a particular article of the Charter.

It would appear that the African Court took the need to judge every claw-back legislation individually into cognisance in Tanganyika Law Society. A careful reading of the case would reveal that the jurisprudence of the Court did not favour total prohibition. The Court appears to accept that a prohibition will be valid if it does not result in

138 Mutua (n 6 above) 358. Also see AE Anthony 'Beyond the paper tiger: The challenge of a human rights court in Africa' (1997) 32 Texas International Law Journal 511 518; G) Naldi 'Limitation of rights under the African Charter on Human and Peoples' Rights: The contribution of the African Commission on Human and Peoples' Rights' (2001) 17 South African Journal on Human Rights 109; R Gittleman 'The African Charter on Human and Peoples' Rights: A legal analysis' (1982) 22 Virginia Journal of International Law 667692.

139 Media Rights Agenda \& Others v Nigeria (n 122 above) para 65.

140 As above.

141 n 27 above para 112.

142 As above.

143 Jawara v The Gambia (2000) AHRLR 107 (ACHPR 2000); Aboubacar v Ghana (2000) AHRLR 124 (ACHPR 1996). 
denying a candidate the right to stand for elections without being a member of, or sponsored by, a political party. ${ }^{144}$

In holding that a particular exception meets the conditions or standards, the African Court would also have to be vigilant enough to ensure, in the case of prohibition of independent candidacy, for instance, that irrespective of the existence of the accepted alternative, the system is not operated in such a way as to obliterate that alternative on technical grounds. ${ }^{145}$ It is, therefore, for the Court to develop broad guiding principles in its own jurisprudence by which each claw-back legislation will have to be judged on its own terms. So long as a claw-back legislation falls within the four corners of the principles, in theory and practice, it should escape a declaration of incompatibility. The ultimate aim should be to ensure that the clauses do not allow derogation that so strikes at the root of an African Charter right as to set it 'aside'146 or 'nullify the very rights and liberties they are to regulate', 147 as this would surely 'defeat the purposes of codifying certain rights in international law and, indeed, the whole essence of treaty making'. ${ }^{148}$

\section{Conclusion}

As a permanent international court and the prime mechanism for the interpretation and enforcement of the African Charter, Tanganyika Law Society \& Another $v$ Tanzania is only the first of many instances where the African Court would find provisions of municipal law, including constitutional texts, incompatible with the African Charter. Now is the time for state parties to the Charter to recognise the huge obligation placed on them by the African Court Protocol and to support the Court to lead the way towards a uniform continental interpretation and application of the Charter. A uniform application of the Charter by the national courts of member states and the African Court would engender jurisprudential harmony as well as promote judicial economy by reducing the desire of individuals to have recourse to the Court as a result of its more favourable jurisprudence. It would also make it possible for all parties to the African Charter to generally observe the same level of Charter obligations.

To achieve coherence and strengthen the standing of the African Court, state parties should be encouraged to make constitutional changes towards accommodating the Court within their legal

144 See 5-6 of this article.

145 See Media Rights Agenda \& Others v Nigeria (n 122 above) paras 55-57; Scanlen \& Holderness $\vee$ Zimbabwe (n 27 above) paras 90-91; also see $\mathrm{F}$ Hoffmeister 'Podkolzina v Latvia App No 46726/99' (2003) 97 American Journal of International Law 3.

146 Media Rights Agenda \& Others v Nigeria (n 122 above) para 66.

147 Tanganyika Law Society (n 4 above) para 109.

148 Constitutional Rights Project \& Others v Nigeria (2000) AHRLR 227 (ACHPR 1999) para 40. 
systems. Such constitutional changes would allow the dualists states to domesticate the African Court Protocol and the monist states to publish the Protocol as a law of the land. Legislative actions would integrate the Court into the legal systems of state parties and ensure a proper line of normativity that allows municipal actors to generally defer to the Court in the interpretation of the Charter as well as in the enforcement of its decisions.

It is to be expected that there will be the real initial difficulty of how to maintain a balance between the innovative interpretation of African Charter articles by the African Court and the diverse interpretations the articles receive across state parties. Important as this is, there is no illusion that the right balance is in the offing. It is even more realistic to note that the balance cannot be achieved under the current system that lacks the needed municipal legal framework recognising the status of the Court in member states. The failure of member states in this regard gives their patently unwilling courts a valid reason, from the municipal law viewpoint, to ignore both the actual decisions and jurisprudence of the Court. Intrinsically, the African Court has a huge role to play: It must seek to build consensus as it incrementally gains legitimacy and trust with every decision it renders, but this will be impossible unless it remains focused and jurisprudentially consistent.

In the final analysis, when all the factors discussed so far are considered alongside the weak AU mechanism that lacks sufficient funds and incentives to compel obedience to African Court decisions, it cannot be said that the Court has the final say yet. 